\title{
Respon Pemberian Pgpr (Plant Grwth Promoting Rhizobacteria) Dengan Dosis Dan Lama Perendaman Terhadap Pertumbuhan Mucuna Bracteata
}

\author{
Irfan Ardiansyah, Nur Ariyani Agustina \\ Universitas Prima Indonesia \\ nurariyaniagustina@unprimdn.ac.id
}

\begin{abstract}
Abstrak
Penelitian ini memiliki tujuan untuk memahami dampak pertumbuhan Mucuna bracteata setelah pemberian PGPR (Plant Growth Promoting Rhizobacteria) dengan dosis dan waktu perendaman yang berbeda. Penelitian ini memanfaatkan metode eksperimental dengan rancangan acak kelompok pola faktorial. Faktor pertama adalah dosis PGPR dengan 4 taraf: 0 $\mathrm{ml}(\mathrm{K} 0), 5 \mathrm{ml}(\mathrm{K} 1), 10 \mathrm{ml}(\mathrm{K} 2), 15 \mathrm{ml}(\mathrm{K} 2)$ dan faktor kedua adalah waktu perendaman dengan 4 taraf: 0 menit (P0), 30 menit (P1), 60 menit (P2), 90 menit (P3). Data dianalisis memanfaatkan sidik ragam (Analysis of Variance) dengan signifikan $5 \%$. Berdasarkan hasil analisa data yang diperoleh bahwa pemberian larutan PGPR memiliki dampak nyata atas jumlah daun, berat kering akar serta berat segar akar. Pemberian larutan PGPR dengan lama perendaman tidak menghasilkan dampak nyata atas berat kering akar, berat segar akar, berat kering tajuk, berat segar tajuk, jumlah daun, panjang sulur, jumlah daun, serta panjang akar. Interaksi antara pemberian larutan PGPR dan waktu perendaman tidak memiliki dampak nyata atas pertumbuhan Mucuna bracteata (berat kering akar, berat segar akar, berat kering tajing, berat segar tajuk, jumlah daun, panjang sulur, jumlah daun, serta panjang akar).
\end{abstract}

Keyword : Mucuna, Rhizobacteria, Dosis, Lama Perendaman.

\section{PENDAHULUAN}

Mucuna bracteata adalah species kacang yang dapat bertumbuh dalam waktu singkat, mempunyai kapabilitas fiksasi $\mathrm{N}$ yang baik, mempunyai toleransi yang baik atas naungan, serta memiliki kandungan sangat senyawa fenolik cenderung tinggi sehingga tidak diminati oleh hewan-hewan ternak ruminansia maupun hama (Harahap et al., 2008). Mucuna bracteta umumnya dimanfaatkan di perkebunan Indonesia karena dibandingan dengan penutup tanah yang lain, tanaman ini mempunyai kandungan biomassa yang lebih banyak. 
Perkebunan karet serta umumnya menggunakan tumbuhan ini pada areal reboisasi (Siagian, 2003). Aktifitas penanaman LCC (legume cover crop) sebagai penutup tanah ini tujuannya mempersiapkan kondisi yang sesuai bagi petani perkebunan khususnya tanaman kelapa sawit dengan harapan mencapai produksi yang tinggi dan menutupi permukaan tanah sehingga menghambat pertumbuhan gulma dan mengurangi kompetisi hara dalam kelapa sawit (Pahan, 2011). Namun, masalah yang sering di hadapi oleh petani dalam mengembangkan tanaman Mucuna breacteata yakni kesulitan akses bibit unggul sehingga mengakibatkan daya tumbuh yang kurang baik. Hal tersebut diakibatkan oleh berbagai macam faktor diantaranya adalah keberadaan unsur hara. Unsur hara adalah faktor yang paling utama untuk media penanaman, akses bagi unsur hara akan berpengaruh terhadap perkembangan tumbuhan yang ditanam di atasnya. Pemupukan biasanya dilaksanakan guna memenuhi kebutuhan tanaman akan unsur hara (Khasanah, 2012).

Dalam meningkatkan pertumbuhan dari tanaman faktor lainnya adalah pengaplikasian Plant Growth Promoting Rhizobacteria (PGPR). PGPR adalah pemicu atau mendorong perkembangan dari berbagai mekanisme yang mengkoloni perakaran melalui bakteri (Ibien $e t$ al., 2012). PGPR merangsang pertumbuhan tanaman sehingga meningkatkan pertumbuhan tanaman karena mempunyai bakteri yang mengkoloni akar dengan mensintesis zat regulator pertumbuhan seperti sitokinin, etilen, asam indol asetatm dan giberelin sebagai penyediaan zat hara yang menangkap $\mathrm{N}_{2}$ di udara secara ambiosis kemudian melarutkan hara $\mathrm{P}$ di tanah, serta sebagai pengontrol patogen tanah (biopractants) dengan cara memproduksi metabolit anti patogen (Husen, et al., 2006). Menurut Santoso et al., (2014) perendaman benih dapat menghasilkan bibit yang unggul dan mempercepat pertumbuhan kecambah. Proses ini juga dilakukan dengan ambisisi yang mengaktifkan enzim enzim didalamnya pada laju reaksi.Perendaman benih perlu diperhatikan kosentrasi dan waktu perendaman supaya tidak terhambatnya perkecambahan (Sutopo, 2010).

\section{METODE PENELITIAN}

\section{Tempat dan Waktu}

Penelitian akan dilaksanakkan di lahan pertanian penduduk di Desa Sidodadi Ramunia, Kecamatan Beringin, Sumatera Utara pada bulan April sampai dengan Juni 2020 Pengovenan dilakukan di PPKS Medan. 


\section{Alat dan Bahan}

Alat yang dimanfaatkan pada studi ini yakni: ayakan, pisau tajam, gunting, cangkul, gembor, gelas ukur, ember, meteran, tali rafia, paranet, bambu, buku, oven, timbangan analitik, kamera, penggaris serta alat tulis.

Bahan yang dimanfaatkan pada studi ini yakni biji Mucuna bracteata, PGPR, polybag $(22 \times 15 \mathrm{~cm})$ dan tanah top soil.

\section{Rancangan Penelitian}

Metode yang dimanfaatkan pada studi ini merupakan metode eksperimen dengan Rancangan Acak Kelompok (RAK) secara faktorial. Faktor I adalah dosis PGPR(Plant Growth Promoting Rhizobacteria) terdiri dari atas 4 kategori: K0 (ml), K1 (5 ml), K2 (10 ml), K3 (15 ml). Faktor II adalah lama perendaman terdiri atas 4 kategori: P0 (kontrol), P1 (5 menit), P2 (10 menit), P3 (15 menit).

\section{Tahapan Penelitian}

Tahapan penelitian meliputi: persiapan areal penelitian, penyiapan bahan tanam, perendaman, penanaman dan pemeliharaan.

\section{Parameter}

Aspek yang diukur berat kering akar, berat segar akar, berat kering tajing, berat segar tajuk, jumlah daun, panjang sulur, jumlah daun, serta panjang akar.

\section{Analisa Data}

Data diolah menggunakan program SPSS v.25. Data akan diuji menggunakanData dianalisa dengan memanfaatkan siik ragam ( Analysis of Variance),dil anjutkan dengan uji DMRT (Duncan'sMultiple Range Test) dengan signifikan $5 \%$.

\section{DISCUSSION}

\section{Panjang Sulur}

Hasil pengamatan panjang sulur Mucuna bracteata dapat ditinjau dari Tabel 1.

Tabel 1. Rataan berat kering akar, berat segar akar, berat kering tajuk, berat segar tajuk, jumlah daun, panjang sulur, jumlah daun, serta panjang akar pada Umur 8 MST

\begin{tabular}{cccccccc}
\hline Perlakuan & $\begin{array}{c}\text { Panjang } \\
\text { Sulur } \\
(\mathbf{c m})\end{array}$ & $\begin{array}{c}\text { Jumlah } \\
\text { Daun } \\
\text { (helai) }\end{array}$ & $\begin{array}{c}\text { Berat } \\
\text { Segar } \\
\text { Tajuk } \\
\text { (helai) }\end{array}$ & $\begin{array}{c}\text { Berat } \\
\text { Kering } \\
\text { Tajuk } \\
\text { (gram) }\end{array}$ & $\begin{array}{c}\text { Berat } \\
\text { Segar } \\
\text { Akar } \\
\text { (gram) }\end{array}$ & $\begin{array}{c}\text { Berat } \\
\text { Kering } \\
\text { Akar } \\
\text { (gram) }\end{array}$ & $\begin{array}{c}\text { Panjang } \\
\text { Akar }(\mathbf{c m})\end{array}$ \\
\hline K0P0 & 153.18 & 43.42 & 29.38 & 6.71 & 2.03 & 0.34 & 26.77
\end{tabular}




\begin{tabular}{llllllll} 
K0P1 & 174.93 & 42.92 & 20.48 & 2.93 & 1.08 & 0.19 & 26.77 \\
K0P2 & 165.02 & 44.22 & 23.67 & 5.98 & 1.88 & 0.31 & 23.22 \\
K0P3 & 176.85 & 54.42 & 21.07 & 4.94 & 1.69 & 0.31 & 27.26 \\
K1P0 & 168.44 & 50.25 & 14.87 & 3.5 & 1.48 & 0.28 & 27.65 \\
K1P1 & 148.17 & 47.47 & 23.33 & 6.10 & 1.96 & 0.35 & 25.29 \\
K1P2 & 167.58 & 57.25 & 35.75 & 6.39 & 2.25 & 0.31 & 25.63 \\
K1P3 & 168.18 & 55.00 & 30.28 & 8.01 & 4.24 & 0.52 & 28.99 \\
K2P0 & 155.45 & 46.83 & 26.63 & 4.42 & 1.46 & 0.41 & 26.08 \\
K2P1 & 245.09 & 49.33 & 23.98 & 5.17 & 1.37 & 0.37 & 26.71 \\
K2P2 & 198.19 & 54.00 & 46.33 & 7.12 & 1.18 & 0.37 & 28.41 \\
K2P3 & 172.02 & 49.17 & 51.06 & 4.51 & 1.43 & 0.28 & 27.90 \\
K3P0 & 168.15 & 55.50 & 34.13 & 5.65 & 5.23 & 0.40 & 26.39 \\
K3P1 & 172.68 & 57.17 & 45.73 & 9.09 & 4.41 & 0.41 & 27.73 \\
K3P2 & 160.88 & 48.42 & 18.58 & 4.88 & 1.63 & 0.43 & 29.88 \\
K3P3 & 326.66 & 54.33 & 25.90 & 13.03 & 2.28 & 0.46 & 30.17 \\
\hline
\end{tabular}

Hasil analisa varians menunjukan bahwa panjang sulur Mucuna bracteatatidak berpengaruh terhadap lama perendaman dan perlakuan interaksi serta pemberian dosis PGPR pada pekan ke-2 hingga pekan ke-8. Ada kemungkinan pada saat pemberian dosis PGPR dosisnya terlalu rendah sehingga tidak berpengaru pada panjang sulur Mucuna bracteata. Menurut Iswati, (2012) dosis yang semakin tinggi akan memberi pengaruh yang makin besar terhadap pertubuhan tanaman. Oleh karena itu interaksi serta lama perendaman antara pemberian PGPR dan lama perendaman yang diapikasikan tidak memberikan dampak untuk komposisi media tumbuh Mucuna bracteata sehingga kurang bekerja dalam meningkatan pembelahan sel dan kerja hormon. Dita (2014) menyimpulkan bahwa interaksi antara lama perendaman PGPR dengan dosisr PGR pada tanaman tidak memiliki dampak yang nyata bagi tinggi tumbuhan, jumlah daun, panjang akar, berat akar. selain itu faktor yang mempengaruhi pertumbuhan tanaman disebabkan oleh lingkungan, cuaca dan lainnya, Hal ini juga didukung berdasarkan penelitian Andrio Sorensen (2015), di musim penghujan dengan curah hujan yang relatif tinggi yang selanjutnya berganti menjadi musim kemarau yang berkepanjangan. Kondisi alam yang ekstrem pada saat penelitian ini bisa mengakibatkan tanaman menjadi tidak menghasilkan bunga maupun biji. Lokasi lahan penelitian juga dapat mengakibatkan plot-plot di lahan studi menjadi kering dan terdapat pecahan pada tanah.

Tabel 2. Pengaruh Dosis PGPR Terhadap Jumlah Daun Tanaman Mucuna bracteata pada Umur 2 dan 6 MST.

\begin{tabular}{|c|c|c|}
\hline \multirow{2}{*}{ Perlakuan } & \multicolumn{2}{|c|}{ Jumlah Daun (helai) } \\
\hline & 2 MST & 6 MST \\
\hline
\end{tabular}




$\begin{array}{lcc}\text { K0 } & 10,57 \mathrm{ab} & 34,97 \mathrm{a} \\ \text { K1 } & 11,67 \mathrm{~b} & 39,67 \mathrm{ab} \\ \text { K2 } & 10,12 \mathrm{a} & 34,89 \mathrm{a} \\ \text { K3 } & 9,77 \mathrm{a} & 41,56 \mathrm{~b}\end{array}$

Keterangan: Angka yang diikuti notasi yang sama menunjukkan perbedaan yang tidak nyata dengan uji beda rata-rata Duncan pada taraf 5\%

Hasil analisa varians menunjukan bahwa jumlah daun tanaman Mucuna Bracteatapemberian PGPR tidak berpengaruh terhadap perlakauan interaksi dan lama perendaman akan tetapi berpengaruh terhadap pemberian dosis biji Mucuna bracteatapada minggu ke-2 dan ke-6 hal tersebut berhubungan dengan perkembangan vegetatif serta kapabilitas tumbuhan untuk melaksanakan proses maupun metabolit yang lain, terdapat 2 aspek yang berpengaruh terhadap perkembangan tanaman yakni: aspek fenotif serta lingkungan sekitar.

Hakim et al. (1989) menyimpulkan bahwa salah satu bagian yang mempunyai peran utama bagi tumbuhan ialah daun. Jumlah daun sangat mempengaruhi hasil fotosintesis, yang nantinya akan memberikan pengaruh bagi pertumbuhan serta perkembangan tumbuhan. Namun berdasarkan uji statistik aplikasi PGPR terhadap pertumbuhan jumlah daun bibit Mucuna bractetatidak berpengaruh pada saat perendaman dan 2 faktor interaksi lama perendaman dan dosis, Hal ini dikarenakan terjadi antara faktor tersebut masih dalam kurang berpotensi dalam merangsang kerja hormon sehingga secara signifikan belum dapat meningkatkan pertumbuhan daun. berdasarkan data Tabel 2 perlakuan $\mathrm{K}$ pada minggu ke-2 dan ke-6 dapat meningkatkan pertumbuhan daun dengan uji SPSS. hal ini disebabkan karena pada saat pemberian PGPR tepat dengan dosisnya.

Tabel 3. Pengaruh Dosis PGPR Terhadap Berat Segar Akar Tanaman Mucuna bracteata pada Umur 8 MST.

\begin{tabular}{cc}
\hline \multirow{2}{*}{ Perlakuan } & Berat Segar Akar \\
\cline { 2 - 2 } & $\mathbf{8}$ MST \\
\hline K0 & $1,67 \mathrm{a}$ \\
K2 & $2,48 \mathrm{ab}$ \\
K3 & $1,36 \mathrm{a}$ \\
\end{tabular}

Keterangan: Angkayang diikuti notasi yang sama menunjukkan tidak berbeda nyata dengan uji beda rata-rata Duncan pada taraf $5 \%$ 
Data rataan hasil pengamatan terhadapberat segar akar tanaman Mucuna bracteta setelah pemberian PGPR pada minggu ke 8 dapat dilihat dari pada Tabel1. Berdasarkan hasil (ANOVA) terdapat pada Tabel 3. bahwa durasi perendaman dan interaksinya kombinasi antara pemberian dosis dan durasi perendaman memiliki dampak yang tidak nyata terhadap berat segar akar tanaman Mucuna bracteata pada 8 MST. Akan tetapi pengaplikasian dosis PGPR berpengaruh terhadap kenaikan berat segar tanaman Mucuna bracteata. Hal ini dikarenakan pada saat pemberiandosis PGPR dosis tersebut bereaksi didalam tanah yang lembabsehingga jumlah terbaik di peroleh pada perlakuan K3P0 dengan hasil $5.23 \mathrm{~g}$. Namun tidak berpengaruh sama sekali dengan perendaman, disebabkan semakin lama perendaman biji Mucuna bracteta dilakukan, maka biji akan menggelembung besar dan kulitnya akan terlepas dapat mengakibatkan munculnya jamur dan tanaman mengalami kematian, Bakteri pada tanah menghasilkan manfaat bagi tumbuhan, namun bakteri dipengaruhi oleh kelembaban tanah, temperature, $\mathrm{pH}$, maupun unsur organik tanah dan mikroorganisme tanah lainnya (Kizilkaya,2009).

Tabel 4. Pengaruh Dosis PGPR Terhadap Berat Kering Akar Tanaman Mucuna bracteata pada Umur 8 MST.

\begin{tabular}{|c|c|}
\hline \multirow{2}{*}{ Perlakuan } & Berat Segar Akar \\
\hline & 8 MST \\
\hline Ko & $28,75 \mathrm{a}$ \\
\hline K1 & $35,75 a b$ \\
\hline K2 & $36,37 \mathrm{ab}$ \\
\hline K3 & $42,67 \mathrm{~b}$ \\
\hline
\end{tabular}

Keterangan: Angka yang diikuti notasi yang sama menunjukkan tidak berbeda nyata dengan uji beda rata-rata Duncan pada taraf $5 \%$

Menurut uji lanjut DMRT dengan kadar 5\% perlakuan pengaplikasian dosis PGPR dapat mempercepat pertumbuhan berat kering akar tanaman Mucana bracteta pada minggu ke- 8 setelah tanam pada perlakuan $\mathrm{K} 3$ dengan dosis $15 \mathrm{ml}$ mencapai hasil sebesar 42,67 $\mathrm{g}$ dan terendah perlakuan $\mathrm{KO}$ dengan dosis $0 \mathrm{ml}$ mencapai hasil 28,75 g. Hal ini menunjukan kenaikan berat kering akar tanaman Mucuna bracteta yang semakin tinggi dipengaruhi oleh tingginya kadar dosis PGPR yang diberikan

Panjang Akar (cm) 
Berdasarkan hasil analsis of varians (ANOVA) bahwa pemberian dosis PGPR dan lama perendaman, sehingga mikroorganisme media tanam kurang berpotensi untuk merangsang pertumbuhan akar. Menurut Anita et al.,(2015),Menjelaskan bahwa faktor dari genetik, morfologi akar juga dipengaruhi oleh ketersediaan hara.jika zat hara yang ada dapat mencukupi nutrisi tumbuhan maka tumbuhan akan menyusun sistem akar yang dangkal, oleh karena itu dalam penelitian ini pada aplikasi pemberian dosis PGPR dan lama perendaman serta kombinasi dosis dan lama perendaman PGPR akar pada tanaman tidak panjang karena unsur hara didalam tanah sudah memenuhi kebutuhan pada tanaman Mucuna bractetata.

\section{KESIMPULAN}

\section{Kesimpulan}

1. Pemberian larutan PGPR berpengaruh atas berat kering akar, berat segar akar, serta jumlah daun tanaman Mucuna bracteata.

2. Pemberian larutan PGPR dengan durasi perendaman tidak berdampak bagi berat kering akar, berat segar akar, berat kering tajing, berat segar tajuk, jumlah daun, panjang sulur, jumlah daun, serta panjang akar tumbuhan Mucuna bracteata.

3. Interaksi antara pemberian larutan PGPR dengan waktu perendaman tidak berpengaruh seluruh parameter pertumbuhan tanaman Mucuna bracteata.

\section{REFERENCES}

Anita Maryam, anas D. susila, Dan Juang Gema Kartika. 2015. Pengaruh Jenis Pupuk Organik Terhadap Pertumbuhan Dan Hasil, Panen Tanaman sayuran Agronomi Dan holtikultura, Fakultas Pertanian, Insitut Pertanian Bogor.

Dewi (2008) menambah akan tetapi tergantung pada dosis larutan yang digunakan dan hormon inilah yang mempengaruhi pertumbuhan tanaman meskipun 
dosis larutan PGPR ditinggikan sampai batas tertentu, tapi perbedaannya tidak signifikan.

Dita, R.S. 2014. Pengaruh dosis dan lama perendaman plant growth promoting rhizobacteria (PGPR) pada pertumbuhan tanaman seledri (Apium graveolens L.) [skripsi]. Pekalongan(ID): Universitas Pekalongan.

Gardner, F. P., Pearce, R.B., Mitchell, R.L. 2008. Fisiologi Tanaman Budidaya. Susilo H,Subiyanto, penerjemah. Jakarta (ID):UI Pr.Terjemahan dari: Physiology of crop plants.

Gusniwati, Salim,H.,Mandasari. 2012. Kelapa sawit (Elaeis gueneenesis Jacq.) di pembibitan utama dengan perbedaan kombinasi pupuk cair Nutrifarm dan NPKMg. Vol.1, No.1. Hal ; 46-55

Harahap,I,Y.2008.

Mucuna bracteata: pemanfaatannya di perkebunan

Pengembanga dan

Husen, E., Saraswati, R., \& Hastuti, R. D. (2006). Rizobakteri pemacu tumbuh tanaman. In R. D. . Simanungkalit, D. A. Suriadikarta, R. Saraswati, D.

Ibien, A.A., J.U. Agogbua, I.O. Okonko and G.N. Nwachi. 2012. Plant growth promoting rhizobacteria (PGPR) as biofertilizer: Effect on growth of Lycopersicum esculentus. Journal of American Science. 8(2) : 318-324.

Iswati, R. (2012). Pengaruh dosis formula pgpr asal perakaran bambu terhadap pertumbuhan tanaman tomat (Solanum Lycopersicum syn). Jurnal Agroteknotropika, 1 (1). kelapa sawit. PPKS. Medan.

Khasanah 2012. Pengaruh Pupuk NPK Tablet dan Pupuk Nutrisi Organik Cair Terhadap Pertumbuhan Bibit Kelapa Sawit (Elaeis guineensis Jacq) di Pembibitan Utama. Skripsi Program Studi Agroekoteknologi. Fakultas Pertanian. Universitas Riau.

Kizilkaya R.,2009. Nitrogen fixation capacity of Azotobacter spp. Strains isolated from soils in different ecosystems and relationship between them and the microbiological properties of soils. J Environ Biol 30(1): 73-82.

Lakitan, B 1996. Dasar-Dasar Fisiologi Tumbuhan. PT Raja Grafindo. Jakarta

Nelson, L. M. 2004. Plant growth promoting rhizobacteria (PGPR): Prospects for new inoculants. Online. Crop Management doi:10.1094/CM-2004-0301-05RV. Samsudin. 2008. pengendalian hama dengan insektisida botani.

Jurnal Insitusi Politeknik Ganesha Medan 
Pahan, I. 2011. Panduan Lengkap Kelapa Sawit Manajemen Agribisnis dari Hulu hingga Hilir. Jakarta: Penebar Swadaya.

Prasasti, O. H., K. I Purwani, \& S. Nurhatika. 2013. Pengaruh mikoriza Glomus fasciculatum terhadap pertumbuhan vegetatif tanaman Kacang Tanah yang terinfeksi patogen Sclerotium rolfsii. J. Sains dan Seni Pomits 2 (2) : $74-$ 78

Rhichardson, A.E., J.M. Barea, A.M. McNeill, and C. Prigent-Combaret. 2009. Acquisition of phosphorous and nitrogent in the rhizosphere and plant growth promotion by microorganisms. Plant Soil 321:305-339.

Santoso Imam, Sulistyani, dan Sudarsianto, 2014. Studi Perkecambahan Benih Kakao Melalui Metode Perendaman. Pusat Penelitian Kopi dan Kakao Indonesia, Jember.

Siagian, Nurhawaty. 2003. Potensi dan Pemanfaatan Mucuna Bracteata Sebagai Penutup Tanah di Perkebunan Karet. Jurnal: Balai Penelitian Karet Sungai Putih

Sorensen, A., Mariati, M., \& Siregar, L. A. (2014). Tanggap Pertumbuhan Vegetatif dan Generatif Bawang Merah Terhadap Dosis Dan Lama Perendaman GA 3 Di Dataran Rendah. Jurnal Agroekoteknologi Universitas Sumatera Utara, 3(1), 103305. 